\title{
RĪGAS POLITEHNIKUMA STUDENTA ALFONA EIHVALDA (1862-1923) IEGULDĪJUMS TUKUMA PILSĒTAS UN SABIEDRISKĀS DZĪVES ATTĪSTĪBĀ
}

AGRITA OZOLA*

Tukuma muzejs

\begin{abstract}
Kopsavilkums. Raksts ir pirmais plašākais pētījums par uzṇēmēju, bankas darbinieku, Tukuma pilsētas pašvaldības vadītāju (1907-1915; 1918-1920) un sabiedrisko darbinieku Alfonu Eihvaldu. Tajā atspoguḷota A. Eihvalda dzīvesdarbība 19. gadsimta beigās / 20. gadsimta sākumā, viṇa loma Tukuma pilsētas pārvaldībā, ekonomiskajā un sabiedriskajā dzīvē - Tukuma Viesīgajā (latviešu) biedrībā un evangéēliski luteriskajā draudzē. Pētījumā izmantots Tukuma muzeja un bibliotēku krājums, Latvijas Nacionālā arhīva dokumenti.
\end{abstract}

Atslēgas vārdi: Alfons Eihvalds, Tukuma pilsētas galva, Tukuma Viesīgā biedrība, Rīgas Politehnikuma studenti.

\section{Ievads}

Kurzemnieks Alfons Eihvalds 19. gadsimta beigās studēja ķīmiju Rīgas Politehnikumā (RP), un viṇa vārds cieši saistīts ar Tukuma pilsētas vēsturi 19. gadsimta beigās / 20. gadsimta sākumā. Pētījumam par A. Eihvaldu un viṇa darbību autore izmantoja Tukuma muzeja krājumā esošos vēstures avotus: Tukuma pilsētas valdes protokolu grāmatas (1913-1915; 1918-1921), kur katru protokolu parakstījis Alfons Eihvalds. Informācija iegūta arī Jāṇa Cera manuskriptā «Tukuma Viesīgās biedrības vēsture (1882-1940)» (1940), Tukuma muzeja darbinieces Latvijas Zinātṇu akadēmijas Goda doktores Intas Dišleres monogrāfijā «Ar ticību, cerību, mīlestību cauri gadu simtiem. Tukuma evanggéliski luteriskā draudze» (2018), Tukuma dzimtsaraksta reǵistros un arhīvu

* Korespondējošais autors.

E-pasts: agritaozola@inbox.lv

(c) 2020 Agrita Ozola. Izdevējs RTU Izdevniecība.

Raksts publicēts brīvpieejā saskanā ar Creative Commons licenci CC BY 4.0.

(https://creativecommons.org/licenses/by/4.0/). 
dokumentos. Vērtējot A. Eihvalda ieguldījumu uzṇēmējdarbības jomā (1894-1912), Tukuma Viesīgās biedrības (1907-1911), vietējās pašvaldības (1907-1915; 1918-1920), Sv. Trīsvienības Tukuma evanggēliski luteriskās draudzes (1920-1923) darbībā, autore guvusi pārliecību, ka viṇš bijis talantīgs pārmaiṇu vadītājs, kas savās darbības jomās pratis izvērtēt esošo situāciju un pieṇemt uz pārmaiṇām orientētus lēmumus, motivēt tām līdzcilvēkus un sekmīgi šīs pārmainas vadīt, būtiski ietekmējot Tukuma pilsētas pārvaldību un sabiedrisko dzīvi pirms Pirmā pasaule kara un Latvijas Republikas pastāvēšanas pirmajos gados.

\section{Alfona Eihvalda izglītība un darba gaitu sākums}

Alfons Kārlis Teodors, saukts par Alfonu, Eihvalds dzimis 1862. gada 8. augustā Bikstu pagasta «Vērpju» māju saimnieku - Kriša (Kristiana) un Lības Eihvaldu - ǵimenē un ieguvis vienu no sava krusttēva, barona Karla Teodora Alfona fon der Ropa (Carl Theodor Alfon von der Ropp; 1809-1883) vārdiem. Jaunpils evaṇgēliski luteriskās baznīcas ierakstā par viṇa dzimšanu tēvam pierakstīts arī otrs uzvārds - Ozoliṇš [1], kas oficiālajos dokumentos vēlāk neparādījās. Alfons mācījās Bikstu pagasta skolā un Jelgavas reālskolā, pēc kuras beigšanas 1884. gada 1. septembrī iestājās RP Ķīmijas tehniskajā nodaḷā. 1888. gada 31. augustā viṇš no politehnikuma izstājās un studijas atsāka tikai 1889. gada 1. septembrī, bet nav apmeklējis nodarbības, tāpēc 1890. gada septembrī svītrots no studentu sarakstiem. Studijas vinš̌ atsāka vēlreiz 1891. gada septembrī un atkal pārtrauca 1892. gada septembrī, tās nepabeidzot [2]. Būdams students, A. Eihvalds 1884. gadā iestājās latviešu studentu korporācijā «Selonija». Viṇa autobiogrāfijā, kas publicēta studentu korporācijas «Selonija» albumā 1905. gadā, rakstīts, ka viṇš pēc izstāšanās no augstskolas trīs gadus strādājis Andreja Zēberga (1855-1932) iesala fabrikā Tukumā, tad kḷuvis par fabrikas vadītāju [3].

1. attēls. Alfons Eihvalds

(20. gadsimta sākums).

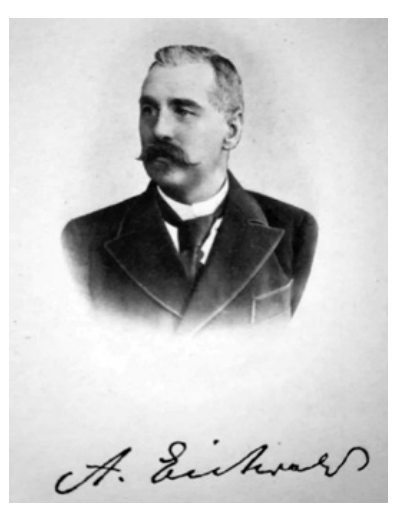


Fabrikas īpašnieks A. Zēbergs spirta brūzi iegādājās 1890. gadā un savā uzṇēmumā attīstīja gan spirta, gan iesala ražotnes. Uzṇēmuma darbība bija sekmīga. Cenšoties pilnībā izmantot visas izejvielas, produkcijas klāstā bija arī iesala konfektes un miežu kafija [4]. A. Eihvaldam izveidojās cieša sadarbība ar īpašnieku, kas turpinājās vairākus gadu desmitus, tomēr vinsš pārtrauca darbu rūpnīcā un pieṇēma citus izaicinājumus.

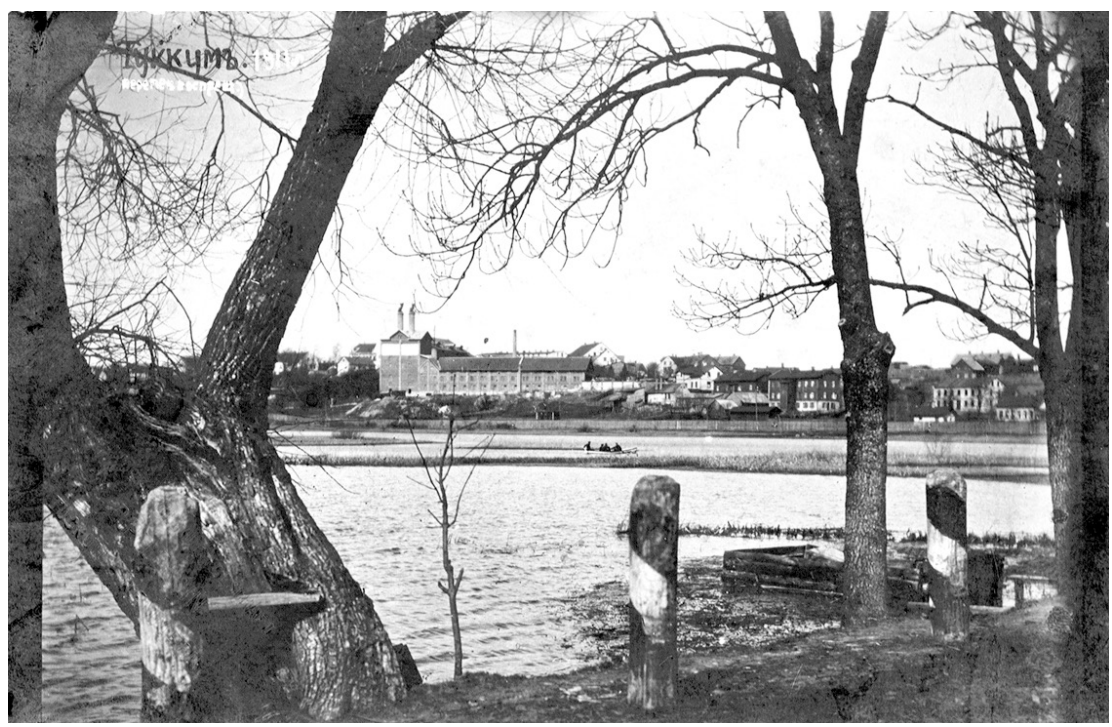

2. attēls. Skats uz Andreja Zēberga rūpnīcu (1911).

1897. gada 10. jūnijā A. Eihvalds kḷuva par gimenes cilvēku. Sv. Trīsvienības Tukuma evangéēliski luteriskās baznīcas laulāto reǵistrā veikts ieraksts Nr. 82 par to, ka Alfons Kārlis Teodors Eihvalds (Eichwald) salaulāts ar Johannu Vilhelmini Kurcigu (Kurtzig), dzim. Jēgeri [5]. Jau pēc dažiem mēnešiem, 1897. gada augustā, A. Eihvalds tika pieñemts darbā Tukuma-Ventspils dzelzcel̦a būves uznēemumā [3]. Eihvaldu ǵimenē 1898. gada martā piedzima dēls Kārlis Alfons, kurš 20. gadsimta 20. gadu sākumā studēja Latvijas Universitātes Tautsaimniecības un tiesību zinātṇu fakultātē [6]. Par dēla tālāko likteni zinnas atrast nav izdevies.

Tukuma-Ventspils dzelzcel̦š ietilpa akciju sabiedrībā «MaskavasVentspils-Ribinskas dzelzcel̦š» (krievu val. - «Московско-ВиндавоРыбинская железная дорога»), kas būvēja vairākas dzelzceḷa līnijas Krievijas ziemel̦rietumu guberñās. Tieši 1897. gada pavasarī pēc cara Nikolaja II izdotā rīkojuma sākās aktīva darbība līnijas projektēšanā, lai nodrošinātu satiksmi no valsts centrālajiem rajoniem ar Ventspils 
ostu [7]. Autores rīcībā šobrīd nav informācijas par A. Eihvalda darba pienākumiem, piedaloties dzelzcel̦a būvē. Tukuma pilsētas maǵistrāta protokolos atrodamas norādes, ka dzelzceḷa būves uzṇēmuma sarunas ar pilsētas maǵistrātu un vietējiem muižniekiem par zemes iegādi pilsētas teritorijā bijušas visai ilgstošas, bet bez rezultātiem. Galu galā stacija Tukums II, lokomotīvju remontdarbnīcas, moderna ūdensapgādes sistēma ar ūdenstorni un pārējā infrastruktūra tapa ārpus pilsētas teritorijas - uz Vilkājas muižas zemes. Līniju Krustpils-Jelgava-Tukums (1901-1904) un Tukums-Ventspils (1904-1908) izveides rezultātā Tukums kluva par nozīmīgu dzelzcel̦a transporta mezglu, bet tas neveicināja pašas pilsētas tehnisko tīklu modernizāciju. Tieši šiem jautājumiem A. Eihvalds pievērsās pēc dažiem gadiem, 20. gadsimta sākumā, kad kḷuva par pilsētas galvu. Iesaistīšanās vienā no lielākajiem Krievijas transporta infrastruktūras attīstības projektiem deva viṇam pieredzi un arī attīstīja stratēgisku redzējumu.

3. attēls. Dzelzcel̦a stacija

Tukums II jeb Rietumu stacija. Pastkarte

(ap 1916).
Rīgas

Politehnikuma

studenta

Alfona Eihvalda

(1862-1923)

ieguldījums

Tukuma pilsētas un sabiedriskās dzīves attīstībā

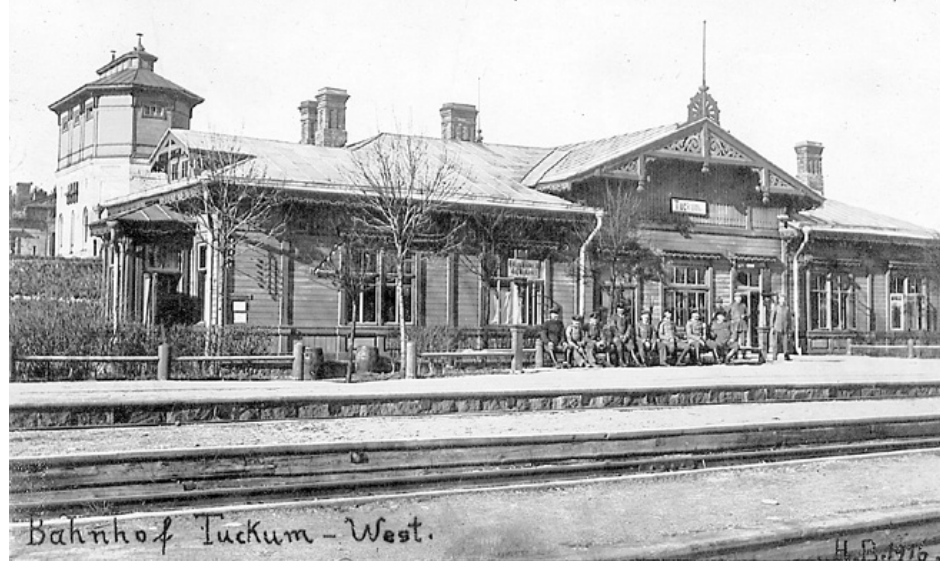

\section{Tirgotāja darbība un īpašumi}

A. Eihvalda dzīvesbiedres Johannas pirmajam vīram, Tukuma rātskungam Johanam Kurcigam (Johann Kurtzig; 1821?-1889), jau 1860. gadā Vecmoku ielā piederēja zemes īpašums ar diezgan blīvu apbūvi [8]. Vismaz no 1860. gada darbojās arī viṇam piederošs spirta destilācijas uzñēmums. Pēc vīra nāves Johanna un viṇas pieci bērni Marija, Johans, Ādolfs, Aleksandrs un Konstantīns - mantoja gan zemes īpašumu, gan spirta destilācijas uzṇēmumu Vecmoku ielā 18 (tagad neapbūvēts laukums Pasta un Talsu ielas stūrī). Johannai Kurcigai piederēja arī 1891. gadā būvēts nams Pils ielā 7 [4]. 


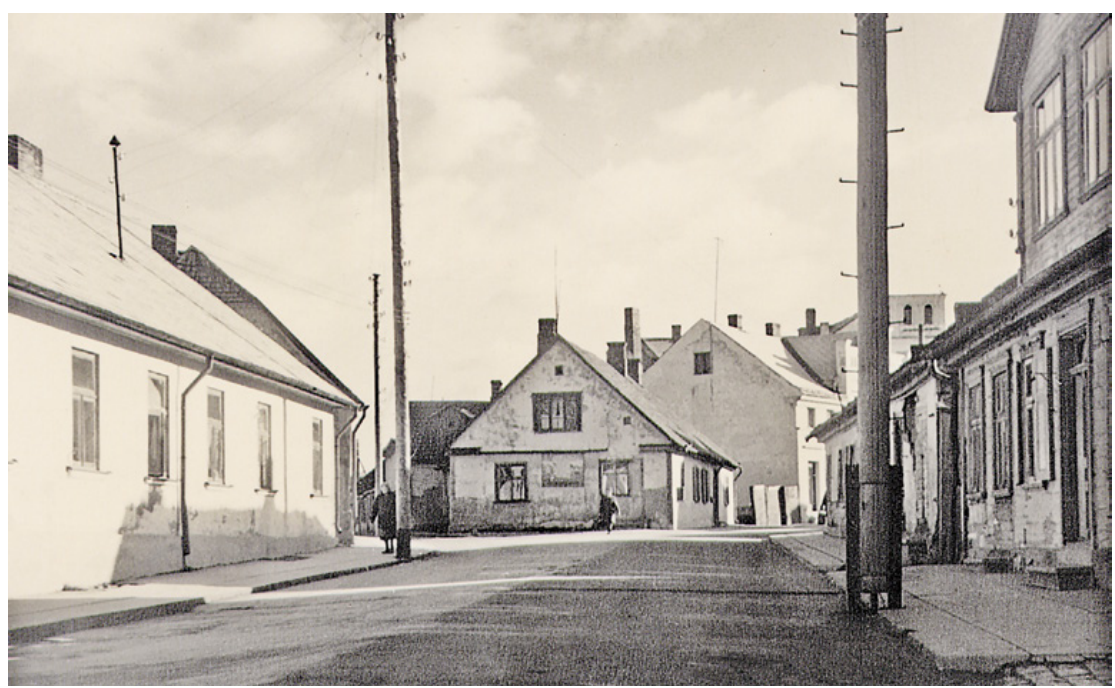

4. attēls. Sarkanarmijas iela Tukumā: centrā bij. Johannas Eihvaldes nams Vecmoku ielā 18 (tagad - skvērs Talsu ielā; 1960).

19. gadsimta beigās arī spirta ražošanas jomā - līdzīgi kā visā saimnieciskajā dzīvē - notika lielas pārmaiṇas. Mazos ražotājus no tirgus izspieda lielās rūpnīcas, kas spēja iegādāties modernas ražošanas iekārtas un izejvielas un izgatavot kvalitatīvāku produkciju lielos apjomos. Salīdzinot ar A. Zēberga uzñēmumu, J. Kurciga brūzis bija visai mazs. Lai modernizētu tehnologisko procesu un izpildītu Kurzemes guberñas akcīzes pārvaldes prasības [9], bija jāveic samērā lieli ieguldījumi. A. Eihvalds, izvērtējis pieejamos resursus, ražošanas procesa efektivitāti un apjomus, ātri saprata, ka Kurciga spirta brūzis nespēs konkurēt ar lielajiem ražotājiem. Iespējams, tieši viṇš vedināja dzīvesbiedri pārtraukt spirta ražošanu. 1899. gada adrešu grāmatā redzams, ka brūzis nepastāv un J. Eihvalde izīrējusi telpas Ernesta Volšmita (?-?), saukta arī par Ozoliṇu, dzērienu tirgotavai [10]. 1901. gadā gruntsgabalā jau bija uzbūvēta jauna dzīvojamā ēka [4].

Vērojot, kā attīstās lielie Rīgas alus brūži un kā tie cenšas iespiesties provinces tirgū ar labas kvalitātes un zemākas cenas alu, A. Eihvalds pēc darba dzelzceḷa būves kompānijā iesaistījās dzērienu tirdzniecībā [9]. 1912. gada Kurzemes adrešu grāmatā atrodama informācija, ka J. Eihvaldei piederošajā gruntsgabalā, Vecmoku ielā 18, atrodas A. Eihvalda vīna un alus tirgotava un Rīgas alus brūža «Tanheizers» noliktava [11] jeb noguldinātava. Konkurenci A. Eihvaldam veidoja četru citu Rīgas lielo alus brūžu - «L. Kymmel», Stricka alus darītava, «Waldschlossen» un Ilǵguciema - noliktavas. Tobrīd pilsētā bija 23 alus bodes un teju tikpat traktieru [11], kas iepirka dzērienus. Jādomā, ka A. Eihvalda uzṇēmuma 
darbība bija visai sekmīga, jo 1907. gadā bija izmaksātas visas mantojuma daḷas visiem rātskunga J. Kurciga mantiniekiem [4].

Eihvaldu otrajā īpašumā, Tukumā, Pils ielā 7, 1909. gadā sētā tika uzbūvēts jauns ērberǵis (mazāka māja, kurā dzīvo kalpu ǵimene). Bija arī liela noliktava. Nākamajā gadā tika modernizēts arī ielas malā esošais nams. Pavisam Pils ielas gruntsgabalā bija 12 celtnu: divas dzīvojamās ēkas, liela noliktava, kūts, škūūini un citas saimniecības ēkas [4]. Telpas tika izīrētas iebrauktuvei (lēta naktsmìtne lauciniekiem) un alus būdai, ko 1912. gadā īrēja M. Būmanis (?-?), kā arī traktierim, ko īrēja F. Neilands (?-?) [11]. Nomnieki mainījās, bet telpas tukšas nestāvēja. 1919. gadā Pils ielas 7. namā bija viesnīca «Central» ar 10 istabām, ko uzturēja Leopolds Leimanis (?-?) un Kārlis Ošs (1883-?) [4].

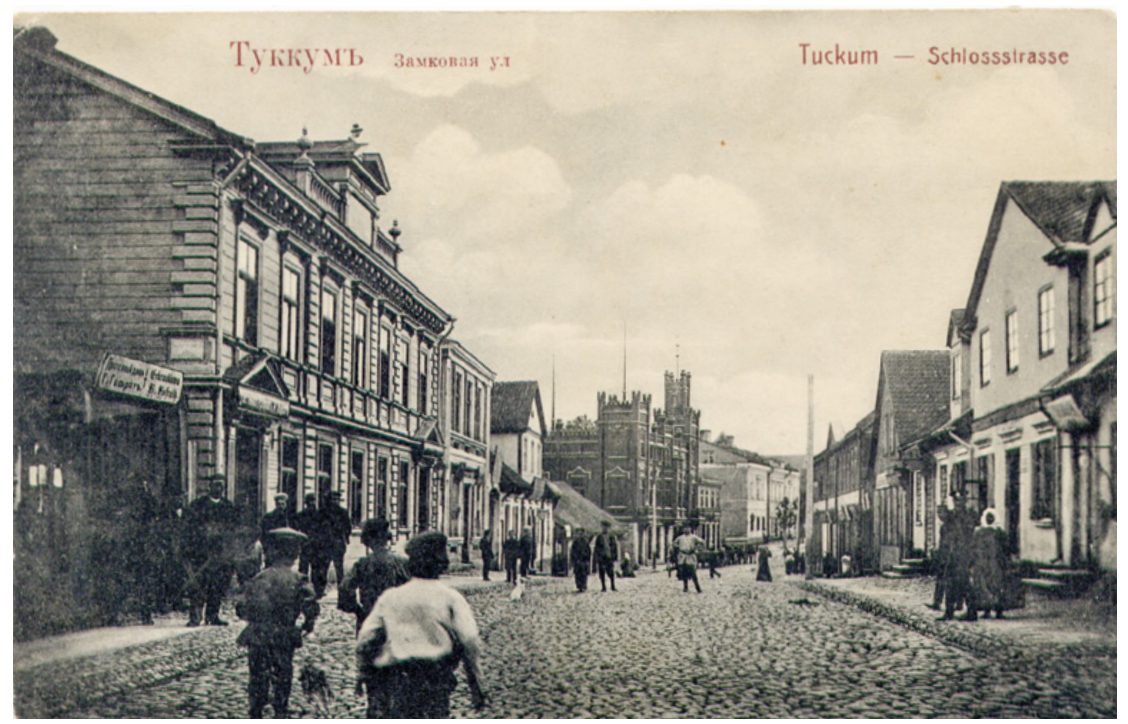

5. attēls. Pils iela Tukumā: kreisajā pusē Eihvaldu nams (tagad - Pils iela 7.

Pastkarte. Tukums: O. Zeldova tipogrāfija; ap 1906).

Abi Eihvaldiem piederošie gruntsgabali atradās pilsētas centrā, galvenajās ielās, netālu no tirgus laukuma. Viens tirdzniecības nams un noliktava atradās Vecmoku un Pasta ielas stūrī, kur bija dzīva satiksme, otrs - Pils ielā līdzās pilsētas visprestižākajām viesnīcām, ēstuvēm un pārdotuvēm. Īpašuma Pils ielā 7 prestižu cēla arī skaistais skats, kas pavērās no namu logiem pāri Slocenes senlejai uz Tukuma dzirnavu ezeru, mežiem un pakalniem, kā arī upes senkrasta piekalnē iekārtotais dārzs ar terasēm. Tas bija iekārojams īpašums. Ne velti to pēc A. Eihvalda nāves nopirka bagātākais Tukuma uzṇēmējs Ansis Ilsums (1853-1941) [4]. 


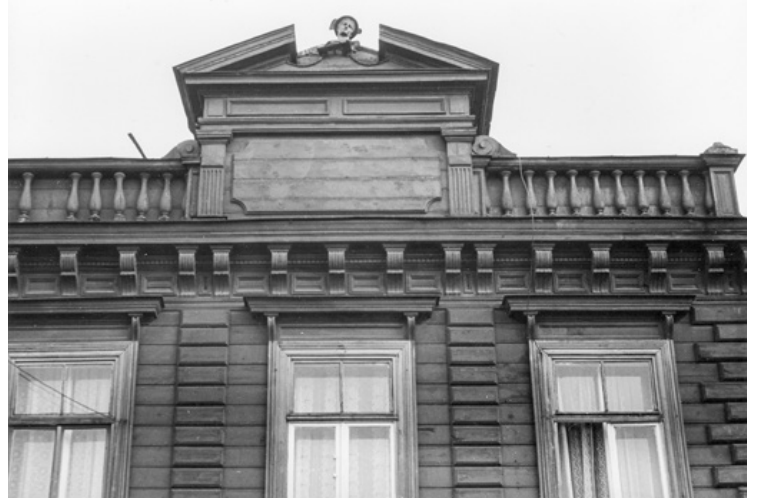

6. attēls. Nams Pils ielā 7, Tukumā (1999). Fotogrāfs I. Smuškova.

Eihvaldu nams Vecmoku ielā nav saglabājies, bet Pils ielā tas joprojām pastāv. Savulaik virs nama centrālā frontona bija novietota pēc īpaša pasūtījuma darināta sengrieķu dievu vēstneša, tirgotāju un cel̦otāju aizbildṇa Hermeja skulptūra [12]. Pētot pieejamās fotogrāfijas, radās asociācijas ar Augusta Folca (1851-1926) darināto Hermeja skulptūru Karla Johana Felsko (Carl Johann Felsko; 1844-1918) projektētas savrupmājas vārtu (1889-1891) noformējumā Bliek,u ielā Rìgā [13].

\section{Alfona Eihvalda darbība Tukuma Viesīgajā biedrībā}

Par A. Eihvalda sabiedrisko darbību 19. gadsimta beigās ir visai maz ziṇu, bet 1902. gada 29. augustā, kad svinīgi atklāja Tukuma Viesīgās biedrības namu, viņš bija apsveicēju vidū, pārstāvot Tukuma Labdarības biedrību [14]. Turpmākajos gados viṇš aktīvi iesaistīiies latviešu biedrības darbībā un 1907. gadā tika ievēlēts par Tukuma Viesīgās biedrības priekšnieku [14]. Viṇa darbība šajā biedrībā saistīta ar visai sarežğìtu laika posmu, kad pēc tā sauktā Tukuma kara (1905. gada 29. novembrī-1. decembrī) biedrība piedzīvoja grūtus laikus. 1905. gada nemieru laikā tās namā atradās sociāldemokrātu aǵitatoru vadītais štābs. Apšaudes laikā cara armijas militārās vienības no dzelzceḷa puses raidītais lielgabala šāviṇš sabojāja nama fasādi. Soda vienība, kas ieradās Tukumā jau 1905. gada Ziemassvētkos, ieṇēma šo namu un biedrībai ieeju tajā liedza. Pēc soda ekspedīcijas pārdislocēšanas namā novietoja citu militāro vienību, kas uzturēja kārtību pilsētā, tāpēc biedrībai neizdevās namu atgūt, un tās darbība apstājās.

Pirmā biedrības valdes sēde pēc ilgāka pārtraukuma notika 1907. gada 1. martā. Valde nolēma rūpēties par karaspēka izvākšanu no nama un pilnvaroja advokātu Jāni Čaksti (1859-1927) sarunām ar valdības pārstāvjiem. Biedrības kopsapulce, kurā par valdes priekšsēdētāju 
ievēlēja A. Eihvaldu, notika 29. aprīlī [14]. Pateicoties vinam, biedrības popularitāte pieauga. Gada laikā biedrībā iestājās 59 biedri, tostarp jaunie uzñēmēji. Tikai 1908. gada 15. janvārī vien biedrībā iestājās 45 jauni biedri. Priekšsēdētāja mērksis bija pierādīt Kurzemes gubernatoram, ka Tukuma Viesīgā biedrība «attālinās no sociāldemokrātu idejām». Viṇa darbības gads noslēdzās ar vizīti pie gubernatora, un tās rezultātā izdevās atdabūt stipri bojāto biedrības kustamo mantu. 17. martā biedrība pat nolēma prasīt pilsētas valdei īres maksu par karaspēka izmitināšanu biedrības namā.

Pēc kopsapulces 1908. gada martā A. Eihvalds atstāja priekšsēdētāja posteni, bet palika valdē, pildot runasvīra pienākumus [14]. No Viesīgās biedrības vēstures teksta var noprast, ka šis ir bijis pretrunu pilns laiks. Autore piel̦auj domu, ka ne biedrības konservatīvais, ne arī kreisi orientētais spārns nebija mierā ar valdes realizēto politiku, kurā liela ietekme bija tieši latviešu izcelsmes uzṇēmējiem, A. Eihvalda domubiedriem.

Kā uzskata starptautiski pazistami amerikāṇu menedžmenta eksperti pārmaiṇu vadības jomā Harolds Sērkins (Harold H. Sirkin), Perijs Kīnans (Perry Keenan) un Alans Džeksons (Alan Jackson), pārmainu īstenošanas sekmes ir atkarīgas no tā, cik spēcīga ir komanda [15]. Autore piel̦auj, ka tobrīd visi biedrības vadošie darbinieki neatbalstīja A. Eihvalda redzējumu un arī biedrības resursi nebija tādi, lai pārvarētu ārējos škēēršlus, tāpēc vin,š turpināja aktīvu darbību valdē kā runasvīrs.

Turpinot sarunas ar guberñas vadību, 1908. gada 18. jūlijā biedrībai izdevās atgūt veikala telpas savā namā. Pārējās telpas biedrība atguva 1908. gada 18. septembrī. Lai risinātu ēkas apsaimniekošanas jautājumus, tika izveidota komisija ēkas bojājumu novēršanai, inventāra iegādei un telpu izīrēšanai. Izveidoja arī zaudējumu aprēksināšanas komisiju un komisiju sarunām ar iespējamo advokātu zaudējumu atgūšanai no guberṇas pārvaldes, kurā ievēlēja A. Eihvaldu. No nama aizzīmogošanas (1905. gada 18. decembris-1906. gada 3. janvāris) un karaspēka izmitināšanas (1905. gada 18. decembris-līdz 1908. gada 18. septembris) rezultātā lēstajiem biedrības zaudējumiem (8194, 16 rubḷi) gubernators atzina lielāko dal̦u (7047 rubḷi), bet nevirzīja atmaksas procesu, tāpēc biedrība nolīga advokātu A. Pētersonu (?-?) [14].

Biedrības popularitāte pilsētā un apkārtnē auga: 1909. gadā tajā iestājās 287 jauni biedri, 1910. gadā - 126 jauni biedri [14]. Tie bija izglītoti, aktīvi un turīgi, tāpēc arī biedrība kḷuva arvien spēcīgāka. Tomēr «bagātībai līdzi nāca godkārība, ārējais spožums un nesaticība,» tāpēc valdei, kurā darbojās A. Eihvalds, l,oti daudz uzmanības nācās veltīt organizācijas kultūras jautājumiem. 1908./1909. gadā biedrību vadīja zemnieku virstiesas priekšsēdētājs Eduards Rause (?-?), kas daudz uzmanības pievērsa biedrības reputācijai, personīgi sekodams Statūtu 
ievērošanai. A. Eihvalds bija ievēlēts īpašajā Sūdzību komisijā biedru izdarīto pārkāpumu izmeklēšanai [14].

Lai arī namu biedrība atguva, tās attiecības ar valsts pārvaldes iestādēm joprojām bija ḷoti saspīlētas. 1910. gada 26. martā valde sañēma gubernatora noraidījumu pirkt šapirogrāfu (teksta, attēla pavairošanas ierīci). 16. jūnijā pēc gubernatora un vietējās policijas pieprasījuma advokātam A. Pētersonam bija jāatsakās no bibliotekāra vietas. Viṇa vietā par bibliotēkas vadītāju gubernators apstiprināja Jāni Freimani (1892-?)[14].

1910. gadā biedrība vairāk uzmanības pievērsa finansiālās situācijas stabilizēšanai. Aktīvāku darbību atjaunoja biedrības teātra trupa, ienesot biedrības kasē prāvas naudas summas. Izrādes bija tik labi apmeklētas, ka biedrība varēja atjaunot namu, plānot jaunu aizkaru iegādi zālei, nopirkt otru biljarda galdu, kā arī atjaunot mācību pabalstus trūcīgiem skolēniem. Piemēram, 13. martā tika nolemts atbalstīt pirmmācības skolas audzēknus [14].

1910. gada 14. septembrī no amata bija spiests atteikties priekšsēdētājs E. Rause, kas bija ierēdnis, un vinna vietā atkal ievēlēja A. Eihvaldu [14]. Pēc Viesīgās biedrības vēstures apraksta noprotams, ka 1911. gadā biedrības dzīvē bija iestājies zināms pagurums, bijušas arī nesaskaṇas vadībā, tāpēc 1 . februārī nolemts pārstrādāt biedrības statūtus. Valdē tika ievēlēti jauni cilvēki: ierēdnis Jēkabs Ieva (1874-1955), kas vēlāk, 1918. gadā, kḷuva par Iekšlietu ministrijas Iekšējās apsardzības nodaḷas priekšnieku, uzṇēmēji: Roberts Ilsums (1883-1918) un Matīss Dambe (1868-1926), kas drīz vien iesaistījās pilsētas pašvaldības darbā [14]. Valde nenogurstoši turpināja uzturēt prasību pret valsti par zaudējumu atlīdzināšanu. Viesīgas biedrības ieñēmumi bija stabili. Tai piederošās Krājaizdevu kases bilance 1912. gadā pārsniedza miljonu zelta rubḷu. Tā bija ierindojusies lielo latviešu kredītiestāžu skaitā [14]. A. Eihvalds ne tikai vadīja biedrību, bet darbojās arī Krājaizdevu kases revidenta amatā [11].

\section{Tukuma pilsētas attīstības vīzijas veidotājs Alfons Eihvalds}

1907. gada 9. novembrī A. Eihvalds kḷuva par Tukuma pilsētas galvu, viṇu šajā amatā ievēlēja uz četriem gadiem. Paziņojumā par vēlēšanām Rīgas vācu laikrakstā «Rigasche Rundschau» viṇš tiek dēvēts arī par Ozoliṇu vai vāciskajā variantā - Ozolingu [16]. 1911. gadā notika nākamās pilsētas domes vēlēšanas. Acīmredzot, pateicoties darbībai Tukuma Viesīgajā biedrībā, A. Eihvalds 1911. gada 14. oktobrī atkal kḷuva par Tukuma pilsētas galvu [11]. Turpmākos 10 gadus - ar pārtraukumu 
Pirmā pasaules kara laikā - vinšs veltīja pilsētas attīstības stratēǵiskajiem un praktiskajiem jautājumiem. Pārskatot Tukuma muzeja krājumā esošos pilsētas valdes protokolus, jāsecina, ka A. Eihvalds bijis visai tālredzīgs. Viṇa prioritāte bija pilsētas teritorijas paplašināšana un modernas infrastruktūras radīšana, tostarp arī ūdensapgādes un kanalizācijas, elektrifikācijas jautājumi, ko iepriekšējās valdes darbības laikā nebija izdevies risināt. Vinš daudz laika veltīja arī pilsētas pamatskolas būvniecības plānošanai, iezīmējot tā sauktos Pravinu laukus (teritorija starp Talsu, Smilšu, Lauku un Raudas ielām) jaunai apbūvei [17].

Sākoties Pirmajam pasaules karam, pilsētas valde bija spiesta risināt karaspēka izvietošanas un ievainoto uzṇemšanas jautājumus, domāt, kā samaksāt ēku īpašniekiem par militārpersonu izmitināšanu, organizēt ziedojumu vākšanu ievainotajiem. Jau 1914. gada 11. augustā valde bija saṇēmusi Kurzemes gubernatora 7. augusta rīkojumu organizēt komiteju slimnīcas aprīkošanai ar inventāru un apgādei ar vel̦u, rūpēties par bēĝ̣lu higiēnu, piemēram, izremontējot pirti. Valdei nācās pildīt daudzus rīkojumus, tostarp izveidot komisiju, lai iesaistītos Kurzemes Sarkanā Krusta līdzekḷu vākšanas akcijā [17]. Pilsētas valdes darbība kara laika apstākḷıs tika stingri uzraudzīta un reglamentēta. Rīkojumi bija obligāti izpildāmi. Piemēram, 15. septembrī saṇemts gubernatora cirkulārs par tādu ielu pārdēvēšanu, kuru nosaukumiem kāda saistība ar Vāciju vai Austroungāriju. Šis laikam bija vienīgais jautājums, ko nevajadzēja risināt, jo tādu ielu Tukumā nebija, tāpēc nekas nebija jāpārdēvē. 6. oktobrī saṇemtais Kurzemes guberñas pārvaldes raksts uzdeva sagatavot telpas Dvinskas kara apgabala karaspēka vienību uzn,emšanai no Viḷnas [17].

Neskatoties uz kara apstākḷiem, pilsētas valde A. Eihvalda vadībā turpināja risināt pilsētai būtiskus infrastruktūras attīstības jautājumus. Vislielākā uzmanība tika veltīta elektrifikācijai. 1914. gada 6. novembrī valdes nolēma samaksāt arhitektam, bijušajam Rīgas Politehnikuma / Rīgas Politehniskā institūta studentam Aleksandram Vanagam (18731919) par veiktajiem darbiem pie elektrostacijas būves. Tika ierīkota arī artēziskā aka Tirgus laukumā [17].

Tuvojoties frontei, situācija kḷuva saspringtāka. Parādījās pirmie bēgli, kurus vajadzēja izmitināt. Auga armijas vajadzības. 1914. gada 4. decembrī valde sañēma rīkojumu samazināt pamatkapitālu par 2000 rubḷiem un novirzìt lazaretes ierīkošanai. 1915. gada 21. maijā pamatskolas telpās izvietotas armijas vienības no Grobiṇas un Talsu apkaimes. 2. jūlijā saṇemts rīkojums evakuēt pilsētas pārvaldi. Kāds bija bēglu cel̦š, vēl nav izdevies noskaidrot. 26. oktobrī Valkā notika valdes sēde nepilnā sastāvā. A. Eihvalds un valdes loceklis J. Jākobsons (18751936) pieñēma lēmumu izmaksāt algas kancelejas darbiniekiem un atbrīvot viṇus no darba veselības stāvokḷa dēl [17]. 


\section{Pilsētas pārvaldes atjaunošana 1918. gadā}

Atgriežoties Tukumā no bēgḷu gaitām 1918. gada ruden̄̄, pilsētas valde atkal atsāka darbu A. Eihvalda vadībā [18]. Pirmā pēckara pilsētas valdes sēde protokolēta 1918. gada 28. novembrī. Tajā skatīja jautājumus par pabalstiem, veikala atvēršanu, komisijas izveidošanu, lai pien,emtu darbā miličus, kas rūpētos par kārtību vācu armijas ien,emtajā pilsētā. Izveidoja arī Apgādāšanas komisiju, lai risinātu pārtikas jautājumus pilsētā, no apriṇķa valdes pārnemtu nabagu patversmi un «zupas katlu». Jau nākamajā sēdē izveidoja trīs Pārtikas komisijas apakškomisijas: labības, cukura un tamlīdzīgu preču sagādei. Valde nolēma arī nomāt Ozolmuižas zemi, lai to varētu pavasarī apsēt un izaudzēt labību un saknes. Valdes locekḷi devās uz apkārtnes muižām iepirkt labību. Apsprieda arī nodevu jautājumu, jo pilsētai trūka līdzekḷu [17]. Valdes rīcība bija l̦oti konstruktīva un izlēmīga.

Vēl pēc nedēlas, 1918. gada 2. decembrī, tika sasaukta domes sēde. Tās protokols liecina, ka pilsētas 26 domnieki Tukuma pilsētas galvas A. Eihvalda vadībā parakstīja lēmumu nosūtīt apsveikuma telegrammu ar šādu tekstu: «Tukuma novada Dome, apsveikdama Latvijas Tautas padomi un Pagaidu valdību, gatava ar visiem spēkiem pabalstīt jaunās valsts pastāvēšanu un zelšanu». Paraksts: «Domes uzdevumā pilsētas galva Eihvalds» [17].

Nestabilās politiskās situācijas dēl 17. decembrī domes sēdē piedalījās tikai deviṇi domnieki, bet viṇi aktīvi risināja pārtikas jautājumus, nosakot, ka visiem, kam lielāki labības krājumi, līdz 1918. gada 20. decembra plkst. 10 jāpiesakās pilsētas valdē, pretējā gadījumā draudot ar labības konfiskāciju. Dome noteica pārtikas normas, kas izdodamas pret pārtikas kartītēm, kā arī maksājamo nodokḷu lielumu par zemi, lopiem, tirdzniecības pakalpojumiem un telpu īri [17]. Pilsētas valde noteica iepirkuma cenas pārtikas precēm un tirgoja tās pašas izveidotā veikalā par noteiktām cenām, izmantojot pārtikas kartītes, tādējādi cenšoties ierobežot spekulāciju.

Ļoti svarīgs bija skolu jautājums. Pats pilsētas galva decembrī iesaistījās skolu darba grupā kopā ar skolotāju Teodoru Dīkmani (18611936), iesala fabrikas īpašnieku un pilsētas valdes locekli A. Zēbergu, ārstu Izidoru Klemptneru (1860-1919) un sāka apkopot datus par skolu situāciju. Turpmākos sešus mēnešus valdes darbība nebija iespējama sakarā ar kara stāvokḷa ieviešanu lielinieku darbības (1919. gada 3. janvāris-22. marts) dēḷ. Pēc pilsētas atbrīvošanas kārtību tajā noteica militārās pārvaldes iestādes, tostarp Baltijas landesvēra virsštābs. Šajā periodā Tukuma Viesīgā biedrība, kuras biedri bija arī pilsētas valdes locekḷi, atkal uzṇēmās iniciatīvu, risinot iedzīvotājiem aktuālos pārtikas un finanšu jautājumus. Piemēram, 1919. gada pavasarī Tukuma Viesīgās 
biedrības Krājaizdevu kase pildīja valsts bankas funkcijas. 1919. gada 26. aprīlī biedrība nodibināja Sarkanā Krusta Tukuma nodaḷu [14].

Tikai 1919. gada 12. jūnijā pilsētas pašvaldība atkal varēja atsākt darbu, sēdē piedaloties arī komandantūras pārstāvim leitnantam Verneram Tepferam (1893-1958). Sapulcējās 16 domnieki, tostarp A. Eihvalds un Jēkabs Bḷodnieks (1849-1929), Jēkabs Ieva (1874-1955), Fricis Strautkalns (1847-?), A. Zēbergs. Pieminēja trīs mirušos domniekus, tostarp lielinieku terora laikā nogalināto Džeimsu Baumgartenu (James Baumgarten; 1879-1919). Dome izteica pateicību amerikāṇu apgādības misijas priekšstāvim majoram V. D. Brūkingam (W. D. Brooking; (?-?)) par miltu sūtījumu un lūdza kartupel̦us, siḷ,kes, ja iespējams, arī taukus [17]. Dome akceptēja A. Eihvalda vienpersoniski pieñemtos lēmumus nomāt Johana Brigena ādgèrētavu Talsu ielā pilsētai piederošo ādu gèrēšanai un Jāna Ilsuma zāgèetavu pilsētai piederošo koku sazāgēšanai. A. Eihvalds arī mērḳtiecīgi turpināja infrastruktūras attīstības stratēgiju, uzdodot A. Zēbergam kopā ar apriṇk,a valdi gādāt, lai rudenī var ievilkt elektrisko apgaismošanu pilsētā [17].

Pilsēta izveidoja Kara zaudējumu komisiju, par tās priekšnieku ievēlot A. Zēbergu, par vietnieku - Jāni Deiču (1866-1926). Lai atrisinātu elektroapgādes jautājumu, valde bija uzñēmusies risku no Vācijas pasūtīt rezerves dal̦as A. Zēberga uzṇēmuma spēka mašīnai, kā arī nopirkt lokomobili no vācu karaspēka un pārṇemt landesvēra elektrostaciju. Dome to atbalstīja [17].

1919. gada 26. augustā apsprieda skolu jautājumu. Pilsētas galva ziṇoja, ka 1919. gadā skolā bija 10 skolotāju un 10 klašu komplektu: sešas latviešu klases, divas vācu un divas ebreju ar 170 bērniem, bet juku dēl mācības varēja notikt tikai divus mēnešus. Nākamajā mācību gadā prognozēja, ka skolā mācīsies 370 bērnu. Pilsētā bija tikai septiṇi skolotāji. Trūka naudas, tāpēc A. Eihvalds rosināja lūgt Izglītības ministriju uzṇemties skolotāju algošanu, jo tādā gadījumā pašvaldība varētu uznemties visus pārējos skolas izdevumus un nodrošināt bezmaksas mācības pamatskolā. N̦emot vērā to, ka daudzi jaunieši kara laikā bija pārtraukuši mācības, Skolu komisija reālskolas (vidusskolas) atvēršanas jautājumus, tostarp cenšoties panākt agrākā Tukuma komercskolas direktora, Rīgas Politehniskā institūta absolventa Jāṇa Stiprā (18701946) pārcelšanu no Valkas uz Tukumu [17].

Sekojot valdības realizētajai zemes reformas idejai, 1919. gada 26. augusta sēdē pilsētas galva A. Eihvalds atgādināja domniekiem par nepieciešamību paplašināt pilsētas teritoriju uz tā saukto obroka (iznomāto zemju) gabalu rēksina. To nomnieki varēja būvēt èkas un pat nodot mantojumā nomas tiesības, bet zemi īpašumā līdz reformai nevarēja iegūt. Viṇš uzsvēra vajadzību iegūt tā saukto Praviṇu krogu centrā tirgus paplašināšanai un Praviṇu laukus (starp Vecmoku, Raudas, Smilšu, 
Lauku ielām) skolu: komercskolas, meiteņu ǵimnāzijas, kā arī renterejas (apriṇksa nodokḷu iekasēšanas iestādes) būvniecībai. Pēc A. Eihvalda ierosinājuma šì zeme uz laiku bija sadalīta mazos dārzinnos, lai trūcīgākie iedzīvotāji paši varētu sevi apgādāt. Dome nolēma vērsties pie Zemkopības ministrijas ar lūgumu iegūt zemi būvniecībai, pie Izglītības ministrijas - lai iegūtu skolas ēkas Lielā ielā 12 un 14 [17].

Pilsētas robežu paplašināšanas jautājums bija A. Eihvalda prioritāte. 1919. gada 26. augustā viṇš domei rosināja izveidot komisiju pilsētas robežu paplašināšanai, pamatojoties uz to, ka faktiski ir izveidojušās jaunas pilsētas dạ̦as: pareizticīgo priesteru lauki, Tīles muiža, luterānu mācītāja lauki un stacijas Tukums II apbūve, kas bauda pilsētas labumus, bet nemaksā nodokḷus, jo atrodas ārpus pilsētas robežām. Komisijā darbojās pats A. Eihvalds, J. Deičs un J. Šablovskis (?-?) [17].

Kara stāvokḷa dẹl pilsētas domes un valdes darbība bija ierobežota. Bermontieši saimniekoja Tukumā no 1919. gada 8. oktobra līdz 22. novembrim, kad 9. Rēzeknes pulks atbrīvoja pilsētu. 6. decembrī beidzot atkal bija iespējams sasaukt domes sēdi, lai apspriestu aktuālos jautājumus. Uzmanība galvenokārt tika veltīta pašvaldības (domes) vēlēšanu sagatavošanai saskaṇā ar Iekšlietu ministrijas Pašvaldību departamenta 1919. gada 25. novembra vēstuli nr. 5487. A. Eihvalds ziñoja, ka pilsētas valde pie iedzīvotāju sarakstu sastādīšanas sākusi strādāt jau oktobra sākumā, taču darbu pārtrauca bermontiešu iebrukums. Viṇš plānoja pēc svētkiem (Ziemassvētkiem) darbu pabeigt, lai varētu iedzīvotāju sarakstu izlikt valdes namā no 1920. gada 2. līdz 15. janvārim izskatīšanai un tālākai rīcībai saskaņā ar Tautas padomes pagaidu noteikumiem [17].

A. Eihvalda rūpju lokā joprojām bija skolu jautājums, piemērotu skolotāju un skolu pārziṇu atrašana, telpu meklēšana un sarunu virzîšana ar Izglîtības ministriju par skolotāju algām, skolu ēku būvniecību. Plašākas debates domē notika par ticības mācības pasniegšanu pamatskolās. Pamatskolu inspektors aizrādīja, ka domes 1919. gada 26. augustā pieñemtais lēmums obligāti skolās mācīt ticības mācību nav atbilstošs Tautas padomes lēmumam. Domes vairākums tomēr palika pie sava: ticības mācība ir obligāts priekšmets pamatskolā, jo tās lēmums pieñemts pirms Tautas padomes lēmuma [17]. Šajā jautājumā spilgti izpaudās arī paša A. Eihvalda nostāja.

\section{A. Eihvalda darbība finanšu jomā}

1920. gada vasarā notika pašvaldību vēlēšanas. A. Eihvalds vairs amatā nepalika, bet pārgāja darbā uz Valsts kasi un kḷuva par Tukuma nodaḷas priekšnieku [18]. Savu atbilstību nodaḷas vadītāja amatam viṇš 
bija pierādījis, darbojoties Tukuma pilsētas pašvaldībā, Tukuma Viesīgās biedrības Krājaizdevu kasē, kā arī «1 rubḷa bēru kasē» (vācu val. - Sterbekasse; nemantīgo iedzīvotāju savstarpējās apdrošināšanas biedrība, kurā varēja iemaksāt nelielu summu (šajā gadījumā - vienu rubli), lai veidotu uzkrājumu bēru izdevumiem un maksai par kapa vietu) [11].

Finanšu jautājumi vienmēr bija A. Eihvalda rūpju lokā. Kā liecina pilsētas pārvaldes protokoli, vin,š izprata valsts monetārās politikas pamatjautājumus un pieejamiem līdzekḷiem centās tos risināt. Esot pilsētas vadībā, viṇš plānoja tās ieṇēmumus un izdevumus. Piemēram, 1919. gada 26. augustā domes sēdē skatīja tā sauktās galvas naudas un noteica nodokli visiem darba spējīgiem vīriešiem no 18 gadu vecuma. Pilsētā bija 1001 nodokḷa maksātājs, no kuriem plānoja ieṇemt 8127 rublus [17].

Risinot pārtikas apgādes jautājumus, pilsētas valde sastapās ne tikai ar problēmu, kur to dabūt, bet arī - kā to izdarīt. Piemēram, 1919. gada augustā valdes loceklim A. Zēbergam bija izdevies Liepājā nopirkt rudzu miltus un ar vilcienu nogādāt Līvbērzes stacijā, kā arī iepirkt cukuru un siḷ,kes. Viṇam bija jābūt visai izveicīgam, jo Liepājā apgrozībā bija tikai vācu nauda, bet Tukumā - lielākoties Latvijas nauda. Lai arī Apgādības ministrija bija uzdevusi visiem tirgotājiem n,emt pretī visu likumīgo naudu, tomēr realitātē tā nenotika. Pilsētas valde, A. Eihvaldam uzstājot, prasīja Pagaidu valdībai noteikt valūtas kursu: Latvijas rubḷa attiecību pret citām valūtām [17].

Arī 1919. gada 19. oktobra sēdē, kurā piedalījās komandantūras pārstāvis. A. Eihvalds runāja par nepieciešamību noteikt valūtas kursu Latvijas rublim, lai normalizētu ekonomisko situāciju pilsētā. Pēc krievu (bermontiešu) kara spēka ienākšanas viens vācu austrumu jeb ostrublis bija divu cariskās Krievijas rubḷu vērtībā, bet Latvijas rubḷa vērtība nebija noteikta. Jelgavā, kur atradās tā sauktās Rietumkrievijas armijas dalıas, apgrozībā bija galvenokārt vācu un krievu nauda, bet Tukumā Latvijas. Caur vietējo valsts kasi bija izgājuši ap 500000 Latvijas rubḷu, jo algas bija izmaksātas Tukumā dislocētās landesvēra vienības, kā arī latviešu komandantūras karavīriem. Valde jau bija lūgusi vietējo garnizona priekšnieku risināt šo jautājumu, bet nesekmīgi. Dome nolēma vērsties pie kara gubernatora, lai tas maina savu rīkojumu un pielīdzina Latvijas rubli austrumu rublim [17]. Šĩ jautājuma virzīšanā izpaudās A. Eihvalda spējas izprast situāciju, saredzēt problēmu saknes un mērḳtiecīgi virzīties uz risinājuma rašanu. 


\section{Evaṇgèèliski luteriskās draudzes pārmaiṇu vadība}

A. Eihvalds piederēja Sv. Trīsvienības Tukuma evan,gēeliski luteriskajai draudzei, kas - tāpat kā visa valsts - arī piedzīvoja lielas pārmaiṇas. Atbilstoši 1919. gada 23. septembra «Pagaidu noteikumiem par evañgèliskām luterāṇu konsistorijām» un 23. decembra «Pagaidu notikumiem par draudžu iekārtu» konsistorijas administratīvajās lietās turpmāk tika pakḷautas Iekšlietu ministrijai, tiesu lietās - Tiesu palātai [19]. Draudze savus darbības jautājumus turpmāk varēja pati izlemt samērā brīvi, protams, atbilstoši spēkā esošajiem normatīvajiem aktiem.

1920. gada 16. janvārī Latvijas Evanggēeliski luteriskās baznīcas Konsistorija izdeva pavēli sarīkot draudžu padomes vēlēšanas līdz 1. martam. Tā paša gada 8. februārī Tukumā sapulcējās visi draudzes vecākie un izveidoja Vēlēšanu komisiju piecu cilvēku sastāvā, par priekšsēdētāju ievēlot A. Eihvaldu. Tika veikta visu draudzes balsstiesīgo locekḷu, kas vecāki par 21 gadu, reǵistrācija. Vislielākā diskusija bija par to, kam piešksirt balsstiesības. 22. februārī Vēlēšanu komisija nolēma dot balsstiesības neatkarīgi no tā, vai persona spēj samaksāt vienu rubli noteikto maksu. Rezultātā Tukuma evanggéliski luteriskajā draudzē pavisam tika registrēti 3955 balstiesīgi locekḷi un noteiktas 32 vietas draudzes padomē. Vēlēšanas notika 21. martā, un tajās par draudzes padomes priekšsēdētāju ievēlēja A. Eihvaldu. 6. aprīlī padomes locekḷi, tostarp A. Eihvalds, deva svinīgo solījumu: «Apsolos uzcītīgi un uzticīgi izpildīt man uzticētos baznīcas draudzes amata pienākumus, kā Dieva vārdā un mūsu evaṇgēliski luteriskās baznīcas mācības, likumi, noteikumi un priekšraksti to prasa, un sekmēt, kā arī veicināt draudzē, cik spēdams, ikkatru labu Dievam patīkamu darbu un pasākumu un ar visu savu dzīvi vārdos un darbos dot citiem labu priekšzīmi» [19].

A. Eihvaldu ievēlēja arī par baznīcas valdes priekšnieku. Viṇa zināšanas, prasmes un līdera spējas palīdzēja nostiprināt draudzes reputāciju un finanšu stāvokli jaunajos apstākḷos. Viens no pirmajiem padomes lēmumiem bija saistīts ar pussabrukušās mācītājmuižas iznomāšanu mācītāja Kārḷa Gustava Matisona (1867-1919) atraitnei un vēl septiñiem nomniekiem, zvejas, medību un niedru griešanas tiesību, muižas dzelzs inventāra, kā arī meža pārdošanu, lai iegūtu naudu mācītājmuižas remontam [19].

1920. gada 20. maijā draudzes padome ievēlēja jaunu mācītāju vikāru Albertu Virbuli (1890-1946) - un 27. jūnijā nodeva tam mācītājmuižu. Inventarizācijas aktu no draudzes puses parakstīja A. Eihvalds. Viṇš pārliecināja padomi sākt remontdarbus [19]. Draudzes padomes vadīšana bija liels izaicinājums, jo ne visi padomes locekḷi apzinājās, ka draudze pati ir savu īpašumu saimnieks. Tukuma muzeja pētniece Inta 
Dišlere secinājusi, ka draudzē nebija izpratnes un pietiekami liela atbalsta mācītājam un padomei šajos jautājumos.

Pēckara apstākḷos draudze un tās locekḷi piedzìvoja lielas materiālas grūtības. 1920. gada rudenī draudze sañēma amerikāṇu palīdzības misijas dāvinājumu: 40 pudu (1 puds ir 16,38 kg) drēbju un apavu, par ko bija jāsamaksā transporta izdevumi - 6 rubḷi par pudu. Pavisam 682 rubl̦us. Lai tādu naudu iegūtu, A. Eihvaldam enerǵiski uzstājot, draudzes padome nolēma 25 labākos sieviešu mētel̦us pārdot padomes locekḷiem par 30 rubḷiem gabalā un pārējās drēbes izdalīt par velti trūcīgākajiem draudzes locekliem [19].

Lai veiktu nepieciešamākos remontdarbus baznīcā un mācītāja dzīvesvietā, tika vākti ziedojumi. 1921. gada 5. jūnijā jau bija savākti 2400 rubḷi. Taču ar to nepietika, tāpēc tika rīkoti tā sauktie bazāri (tirdziṇi), aicinot draudzes dāmas pārdot savus darinājumus. Ieṇēmumi no bazāriem l̦āva 1921. gadā izbūvēt sētu ap baznīcu, 1922. gadā - saremontēt baznīcas jumtu, salabot ērǵeles, ievilkt elektrību un veikt citus darbus [20]. 1923. gada 9. martā A. Eihvalds izteica «izjustu pateicību visiem, kas sekmējuši bazāra sarīkošanu ar tik kupliem panākumiem, sevišk̦i bazāra komitejai un vin,as priekšniekam Ž. Grīnhofam» [19].

Pēc kara draudzes locekḷu skaits bija samazinājies, jo daudzi vairs pie dievgalda negāja [20]. Pateicoties mācītāja A. Virbuḷa un draudzes padomes priekšsēdētāja A. Eihvalda personībām, daudzi tomēr atkal atgriezās draudzē. 1923. gada 27. maijā A. Eihvaldu atkārtoti ievēlēja par draudzes padomes priekšsēdētāju [19]. Šajās vēlēšanās ieviesa A. Eihvalda ierosināto principu, ka vēlēšanās piedalās tikai tie, kas maksā draudzes nodokli (294 personas), tāpēc arī valdes locekḷu skaits samazinājās līdz sešiem [20]. Tas padarīja valdi vieglāk vadāmu un rīcībspējīgāku. Mācītājs A. Virbulis vēlāk rakstīja, ka baznīcas padomes locekḷi, «izṇemot valdes locekḷus un vēl nedaudzus, izrādījuši diezgan maz intereses par saviem pienākumiem» [20]. Nedaudzo atbalstītāju skaitā bija arī fabrikants A. Zēbergs, kas 1923. gadā ziedoja 20000 rubḷu baznīcas zvana iegādei [20].

Diemžēl A. Eihvalda dzīve drīz vien aprāvās. 1923. gada 11. jūlija sēdē Tukuma pilsētas dome godināja A. Eihvalda piemiṇu [14]. Viṇa vietā 31. jūlijā ievēlēja Žanno Grīnhofu (Jeannot Bruenhof; 1884-?). Apspriežot A. Eihvalda ieguldījumu draudzes darbā, valde apsvērusi iespēju viṇa kapu kroni likt gēerbkambarī vai baznīcā. Mācītājs A. Virbulis esot ierosinājis uzlikt marmora piemingas plāksni [20], bet visticamāk tas tomēr nav darīts. 


\section{Nobeigums}

Bijušā Rīgas Politehnikuma studenta Alfona Eihvalda ieguldījums Tukuma pilsētas attīstībā, pašvaldības veidošanā un pārvaldībā, kā arī tās sabiedriskajā un ekonomiskajā dzīvē līdz šim nebija izvērtēts. Autore uzskata, ka A. Eihvalds mūsdienu izpratnē būtu dēvējams par pārmainu vadītāju, kurš savus talantus un zināšanas visspožāk parādīja tieši brīžos, kad bija vajadzīgas pārmaiṇas: pēc 1905. gada nemieriem, Pirmā pasaules kara sākuma posmā, Latvijas valsts veidošanas periodā. Viṇš pievērsa valsts pārvaldes iestāžu uzmanību naudas sistēmas sakārtošanas aktualitātei un veidoja un vadīja Valsts kases Tukuma nodalıu, kā arī lika pamatus Sv. Trīsvienības Tukuma evangéēliski luteriskās draudzes padomes darbībai demokrātiskas valsts apstākḷos.

Tukumnieks A. Eihvalds uzdrošinājās stāties Tukuma Viesīgās (latviešu) biedrības priekšgalā pēc 1905.-1907. gada nemieriem un pamatot biedrības tiesības uz savu namu, savu īpašumu reakcijas apstākḷos. Viṇš arī pārveidoja biedrību, padarot to par finansiāli spēcīgu organizāciju, kurai Tukuma pilsētas sabiedrībā bija ne tikai laba reputācija, bet arī spēcīga ekonomiskā ietekme. Tā uzṇēmās latviešu izcelsmes uzṇēmēju atbalsta funkciju cariskās Krievijas reakcijas periodā pēc 1905. gada, kā arī pirmajā Latvijas valsts darbības gadā, kad nacionālā banka vēl nebija nostiprināta.

A. Eihvalds bija viens no pirmajiem A. Zēberga spirta rūpnīcas ražošanas vadītājiem, kas bija studējis k̦īmiju un varēja organizēt ražošanas procesu atbilstoši tehniskajiem un sanitārajiem noteikumiem. Viṇš 19. gadsimta beigās pārprofilēja veco J. Kurciga spirta brūzi, saprotot, ka tas nespēs izpildīt akcīzes valdes noteikumus un izturēt augošo lielo uzṇēmumu konkurenci. Vinšs izvēlējās darboties dzērienu tirdzniecības jomā, kas varēja dot pietiekami lielus ieṇēmumus gimenei, attīstīt īpašumus un arī nodrošināt zināmu prestižu pilsētas sabiedrībā.

Pieñemot izaicinājumu darboties Tukuma-Ventspils dzelzceḷa būves uzṇēmumā, A. Eihvalds guva pieredzi lielu projektu darbībā, zināšanas par dzelzcel̦a transporta un tā atbalsta infrastruktūras organizāciju, lai vēlāk to liktu lietā pilsētas infrastruktūras attīstībā. Pēc savas būtības viṇš bija pilsētas attīstības vizionārs, kas ideju par pilsētas teritorijas paplašināšanu un tehniskās infrastruktūras modernizāciju sāka realizēt jau pirms Pirmā pasaules kara, iezīmējot tālāko attīstības līniju, kas tika realizēta Agrārās reformas laikā starpkaru periodā. Viṇš daudz darīja skolu attīstībā un aktīvi iesaistījās nacionālās izglītības sistēmas finansējuma modeḷa veidošanā, akcentējot valsts un pašvaldību sadarbību. 


\section{ATSAUCES}

[1] Jaunpils draudzē dzimušie, 1862. gads. Latvijas Nacionalā arhīva Latvijas Valsts vēstures arhīvs (turpmāk - LNA LVVA) 235. F., 2. Apr., 875. l., 139. lp. o. p.

[2] Rīgas Politehnikuma studentu saraksti. LNA LVVA 7175. f., 1. apr., 1903. l., 14. lp.

[3] Graudiňš, K. Selonijas albums, 1880-1905. Jelgava: G. Lansberǵis, 1905, 72. lpp.

[4] Ozola, A. Tukums. Vecpilsēta: ielas, nami un to iedzīvotāji. Tukums: Tukuma muzejs, 2007, 342., 421. lpp.

[5] Tukuma draudzes laulātie un mirušie, 1897. gads. LNA LVVA, 4799. f., 1. apr., 4. l., 49. lp.

[6] Kārḷa Alfona Eihvalda studenta lieta. LNA LVVA 7175. f., 1. apr., 5867. l.

[7] Sputnik po Moskovsko-Vindavskoj zheleznoj doroge. Moskva: S.P. Jakovlev, 1909, s. X, 338, 17.

[8] Tukuma pilsētas maǵistrāts. Kurciga īpašums Tukumā, Vecmoku ielā. LNA LVVA 653. f., 2. apr., 80. l.

[9] Rank̦evics, A. Alus brūvēšana Latvijā (1800-1915). Tukuma novada kultūrvēsture. Tukuma muzeja rakstu krājums, 10. sējums. Tukuma muzejs: Tukums, 2010, 65., 83. lpp.

[10] Richter, A. Baltischer Verkehrs un Adressbucher. I Band, Kurland. Riga: 1900.

[11] Richter, A. Baltischer Verkehrs un Adressbucher. II Band, Kurland. Riga: 1912, S. 253., 258., 259., 261., 262.

[12] Pils iela Tukumā: kreisajā pusē Eihvaldu nams (tagad - Pils iela 7). Pastkarte. Tukums: O. Zeldova tipogrāfija, ap 1906. gadu. Tukuma muzeja inv. nr.: TMNM 667.

[13] Vārti Blieḳu ielā, Rīgā. Arhitekts K. Felsko, tēlnieks A. Folcs [tiešsasite]. https://www.makslasvesture.lv/Att\%C4\%93ls:Folcs_Varti_Blieku_iela.jpg. [skatīts: 24.01.2020].

[14] Tukuma Viesīgās biedrības vēsture. Jāṇa Cera manuskripts, 1940, 34., 49., 50., 52., 53., 54., 55., 56., 57., 65., 69., 71., 73., 77., 79., 83. Ipp. Tukuma muzeja inv. nr. TMNM 10140.

[15] Pārmainu vadība. Grāmatu sērija «Harward Business Review on». Rīga: Lietišķās informācijas dienests, 2008, 141. lpp.

[16] Tuckum. Bestaetigung. Rigasche Zeitung, 20. November 1907, No. 270, S. 3.

[17] Tukuma pilsētas valdes protokoli (1913-1915, 1915-1923), 56., 63., 66., 68., 69., 71., 72., 74.-78., 80., 83., 89., 93. lpp. Tukuma muzeja inv. nr. TMNM 1648.

[18] Ozola, A., Smuškova I., Znotiṇa, I. Viss sākās ar Viesīgo biedrību jeb tādi mākslinieki ir tikai Tukumā. 1882-2002. Tukums: Tukuma muzejs, 2002, 141. Ipp.

[19] Dišlere, I. Ar ticību, cerību, mīlestību cauri gadu simtiem. Tukuma evan,gēeliski luteriskā draudze, 2017, 128., 129., 298., 563. lpp. 
[20] Tukuma evangéēliski luteriskās latviešu draudzes padomes sēžu protokoli ar pielikumiem. 27.05.1923 - 18.09.1940. Citēts: Dišlere Inta. Ar ticību, cerību, mīlestību cauri gadu simtiem. Tukuma evanǵgèliski luteriskā draudze, Rīga: Tukuma ev. lut. draudze, 2018, 128.,130, 131.,133. lpp.

\section{ILUSTRĀCIJU AVOTI}

1. attēls. Graudiṇš, K. Selonijas albums, 1880-1905. Jelgava: G. Lansberǵis, 1905, X lpp.

2. attēls. Tukuma muzeja inv. nr. TMNM 18120.

3. attēls. Tukuma muzeja inv. nr.: TMNM 27428.

4. attēls. Tukuma muzeja inv. nr. TMNM Pgm 708.

5. attēls. Tukuma muzeja inv. nr.: TMNM 667.

6. attēls. Tukuma muzeja inv. nr. TMNM Pgm 2215/21.

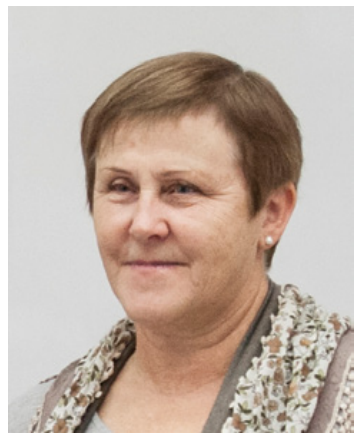

AGRITA OZOLA is the director of Tukums museum (since 1987). She holds a Master's degree in History and a Master's degree in Sciences. She finished doctoral studies in Environmental Sciences in 2003. She was a lecturer at the University of Latvia in 2000-2012 in the field of the cultural environment and applied heritage. Since 2001, she has been a lecturer at the Academy of Culture of Latvia where she is teaching courses on Museum Management and Museum Education. She has given several courses in further education for museum professionals on museum management, exhibiting and education. She is the author of 18 scientific articles on cultural environment and heritage interpretation, and museological themes, as well as the author of 4 and co-author of 10 books.

E-mail: agritaozola@inbox.lv

Agrita Ozola

\section{The Contribution of Graduate of Riga Polytechnicum Alfons Eihvalds (1862-1923) to the Development of the Tukums Town}

The article is the first comprehensive study on businessman, bank employee, Mayor of the Tukums town municipality (1907-1915; 1918-1920) and public employee Alfons Eihvalds. It reflects the life of A. Eihvalds at the end of the 19th century / beginning of the 20th century, his role in the management of Tukums town, its economic and social life - Tukums Sociable (Latvian) Society and Evangelical Lutheran Congregation. The research uses the collection of Tukums Museum and Libraries, and documents of the Latvian National Archives.

Keywords: Alfons Eihvalds, Mayor of Tukums, Tukums Sociable Society, students of Riga Polytechnicum. 